\title{
Endoscopic Submucosal Dissection, a New Technique for en Bloc Resection of Large Superficial Tumor in the Esophagus
}

\author{
Makoto Nishimura, Masafumi Sakaguchi, Hideki Kitada, \\ Michio Hifumi and Hiroto Kita \\ International Medical Center, Saitama Medical University \\ Japan
}

\section{Introduction}

For superficial esophageal cancer, conventional endoscopic mucosal resection with cap (EMRC) has been widely prevailed for reliable and safety treatment ${ }^{1}$. Recent innovations of diagnostic endoscopy including high-resolution endoscopy, narrow band imaging (NBI), and magnified endoscopy allow detect and identify more small lesions of the GI tract, and endoscopist are forced to develop their skills for endocopic treatment. Recently, endoscopic submucosal dissection (ESD) has been developed for en bloc resection of larger superficial tumor in the GI tract than conventional EMR. In this decade, ESD has been widely accepted as a more reliable therapeutic procedure than EMR in Japan, and various devices are developed.

Of the esophageal cancers, squamous cell carcinoma is the most common carcinoma in Japan, and iodine staining endoscopy has been widely used to detect esophageal SCC. Conventional EMRC has been performed for these 10 years, however, since conventional EMRC were carried out with small size cap, $12 \mathrm{~mm}$ in diameter, there has been the risk to be piecemeal and residual lesions. Recently, newly classification of intrapapillary capillary loop pattern (IPCL) has developed for diagnose the early esophageal neoplasm, and because of these diagnostic innovation, therefore, many endoscopist are forced to remove larger en bloc resection for reliable ESD as well as gastric or colorectal lesions. Therefore, in Japan, ESD for large superficial esophageal neoplasm has been applied; however, esophageal ESD is considered as more difficult and challenging than gastric ESD, and only few studies have elucidated the technical feasibility of ESD in the esophagus.

Needle knife has been used for early gastric and colorectal ESD, and it has been considered causing high complications for esophageal ESD because of its sharpness. For this reason, using other knives, some clinical case series are reported for esophageal ESD, and the safety of esophageal ESD using needle knife is still unclear. In this study, we conducted consecutive esophageal ESD with needle knife and compared EMR to evaluate safety and reliability of needle knife as esophageal ESD device.

\section{Patients and methods}

Between February 2001 and March 2009, a total of 82 patients with esophageal squamous cell neoplasm were treated by ESD or EMRC at our institution. Data was stored 
consecutively in the database that include patients information, lesion sizes, histopathologic findings (depth, negative rate of lateral margin, negative rate of vertical margin, lymphovascular invasion), treatment type, complications, and prognosis. Based on initial endoscopic evaluation, patients were selected endoscopic treatment, radiation, chemoradiation, or surgery. Criteria of endoscopic treatment for superficial esophageal tumor at our institution were the follows; (1) previously proven squamous-cell carcinoma (SCC) or dysplasia which cannot rule out concomitant with SCC, up to $75 \%$ circumference, (2) supposed to be mucosal or mild submucosal invasion endoscopically, (3) no obvious evidence of lymphovascular invasion echoendoscopically, (4) no prior esophageal surgery, (5) no severe cardiovascular complications. Ulcerated lesion, advanced SCC, adenocarcinoma, $100 \%$ circumferential lesion, and patients with severe cardiopulmonary complications were excluded. Written informed consent was obtained from each patient, while conventional surgery or standard chemoradiation with 5-FU/CDDP+RT were offered as options before treatment. After initial treatment, all cases were observed (mean period: 37.2 months, range: 8-103 months), and the local recurrence rate and overall survival period of each group were analyzed.

\subsection{Statistical analysis}

Data were collected and analyzed. Comparisons between groups were performed $\chi^{2}$ test for categorical variables. A P value $<.05$ was considered statistically significant. All analysis were performed on a personal computer by using IBM SPSS version 15 (IBM SPSS 19, IBM, Co, Sorners, NY).

\subsection{Cap-EMR technique}

With standard panendoscope (GIF-240Z, Olympus Optical, Tokyo, Japan), endoscopic mucosal resection using a cap (EMRC) was carried out under conscious sedation as followed; marking were placed with needle knife, 2) EMR cap was fitted to the tip of standard panendoscope, 3) targeted lesion was elevated by the submucosal injection, 4) the lesion was then sucked into the cap and strangulated by closing the snare, 5) the lesion was resected by the application of electric current.

\subsection{ESD technique}

For ESD, standard endoscope was used with an attachment (D-201-11804; Olympus, Japan). Briefly, ESD was conducted under conscious sedation as followed; 1) marking were placed with needle knife (KD-10Q-1; Olympus, Tokyo, Japan) around the targeted lesion, 2) $0.5 \mathrm{ml}$ normal saline and $1.0 \%$ of sodium hyaluronate were injected into submucosal layer, 3 ) using electrocosurgical generator (VAIO, Erbe Co, Tubingen, Germany), needle knife was used for circumferential cutting and submucosal dissection, and the elevated lesion was performed en-bloc resection. Hemostastic forceps (Coaglaspa, Olympus, Japan) was used for hemostasis. In both groups, all resected specimen were retrieved and histopathologically evaluated.

\section{Results}

From the database, we corrected 82 patients who underwent esophageal treatment endoscopically. The feature of the patients and lesions are shown in Table 1. Complete 
resection was achieved in all 82 patients. Sixty-one patients were treated by ESD ( 57 males, median age 67.5, range 38-87) and 21 patients were treated by EMRC (19 males, median age 66.0, range 46-83). Between both groups, there were no significant differences in patients characteristics; age and $\operatorname{sex}(\mathrm{p}=0.530$ vs $\mathrm{p}=0.653)$. The tumor size was significantly larger in the ESD group than EMRC group; the mean resected specimen size was $21.4 \mathrm{~mm}$ in diameter (range 12-40 $\mathrm{mm}$ ) for EMRC and $31.3 \mathrm{~mm}$ in diameter (range 8$50 \mathrm{~mm}$ ) for ESD $(\mathrm{P}<0.001)$. The en-bloc resection rate was $61.9 \%$ and $98.4 \%$ in the EMRC and ESD groups, respectively $(\mathrm{P}<0.01)$. Histopathologically, there were 52 cases of squamous cell carcinoma (SCC) and 9 dysplasias in the ESD group, while 14 cases of SCC and 7 dysplasias in the EMRC group. The negative horizontal margin rate was $85.7 \%$ and $90.1 \%$ for the EMRC and ESD groups, respectively $(\mathrm{p}=0.574)$. The negative vertical margin rate was $95.2 \%$ and $90.8 \%$ for the EMRC and ESD groups, respectively $(\mathrm{P}=0.726)$. There were 0 cases in the EMRC group and 9 cases of complications in the ESD group ( 5 cases of stenosis and 4 cases of perforation). Among the patients with perforation in ESD group, 1 case was successfully treated by emergency surgery and others were managed conservatively, however, could not evaluated tumor depth histopathologically because of the patient's status. The local recurrence rate was 5.0 in the EMRC group and $1.6 \%$ in the ESD group $(\mathrm{P}=0.42) .2$ patients died from radiative pneumonia and 1 patient died from acute myocardial infarction in the EMRC group, and 1 patient died from pancreatic cancer in the ESD group, and. No patient in either group died from any associated complications or esophageal cancer.

EMRC ESD $P$ value

\section{Patients characteristics}

Number of patients

Mean age (y)

Male/ Female

Characteristic of lesions

Histologic type

Mild dysplasia

Moderate dysplasia

Severe dysplasia

Squamous cell carcinoma

Table 1. Patient characteristics
21

66

$19 / 2$
61

67.5

0.530

0.653
1

4

2

14
0

4

4

53 

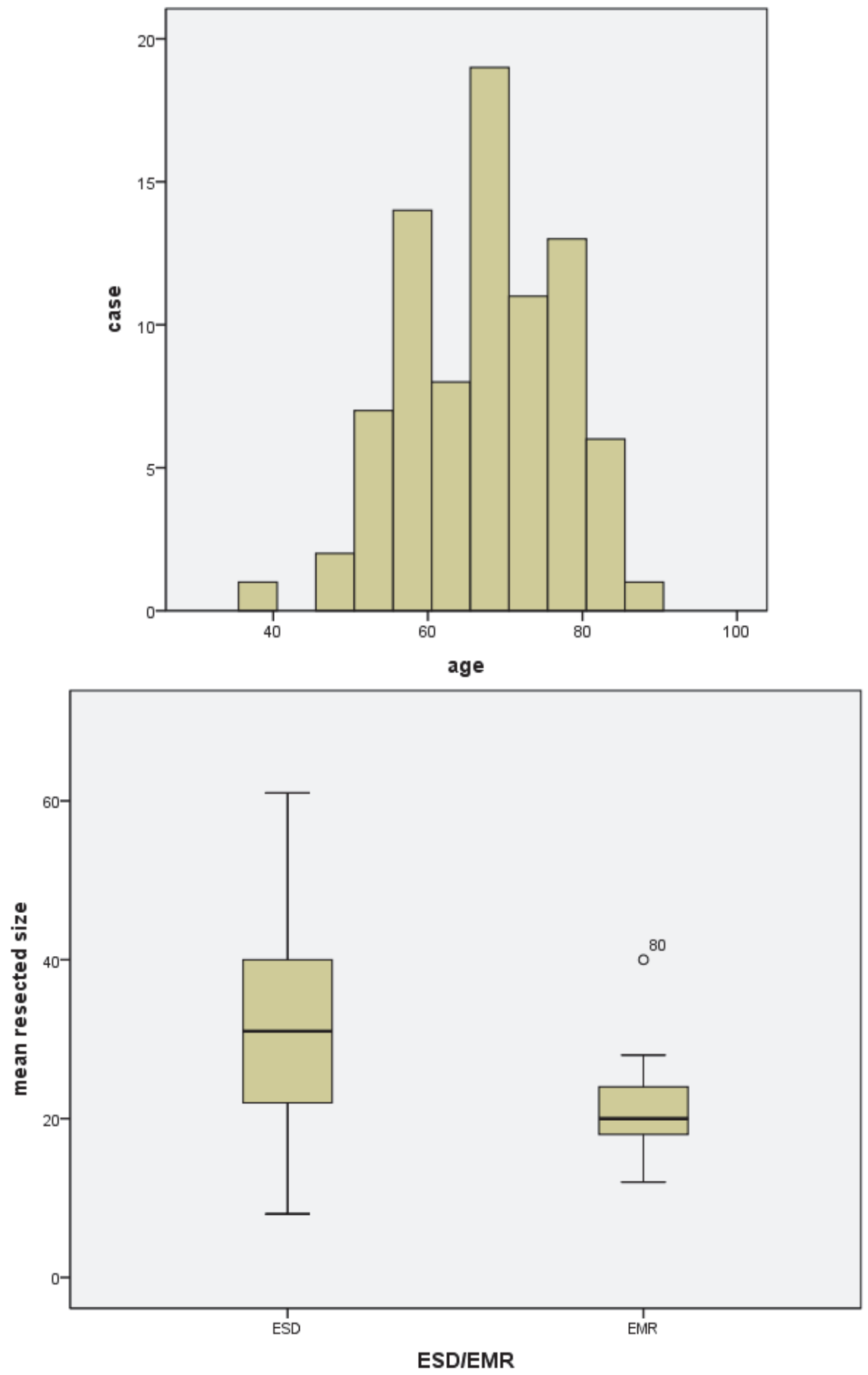


\begin{tabular}{llll} 
& EMRC & ESD & \\
\hline \hline mean resected size(mean [SD]) (cm) & $21.48 \pm 2.63$ & $31.34 \pm 2.97$ & $\mathrm{p}<0.001$ \\
en-bloc resection no, rate (\%) & $13 / 21(61.9 \%)$ & $60 / 61(98.4 \%)$ & $\mathrm{p}<0.001$ \\
Deapth of the tumos & & & \\
Dysplasias & 7 & 9 & \\
m1 & 2 & 30 & \\
m2 & 5 & 7 & \\
m3 & 5 & 9 & \\
sm1 & 1 & 2 & \\
sm2 & 0 & 3 & \\
sm3 & 1 & 0 & \\
unknown & & 1 & \\
\hline LM negative no, rate $(\%)$ & $18 / 21(85.7 \%)$ & $55 / 61(90.1 \%)$ & $\mathrm{p}=0.574$ \\
VM negative no, rate $(\%)$ & $20 / 21(95.2 \%)$ & $55 / 61(90.1 \%)$ & $\mathrm{p}=0.726$ \\
local recurrence no, rate $(\%)$ & $1 / 20(5 \%)$ & $1 / 61(1.6 \%)$ & $\mathrm{p}=0.42$ \\
\hline
\end{tabular}

Resected size; Manan-Whiteney test $\mathrm{p}<0.001$

En-bloc/piecemeal Peason $\chi^{2}$ test $\mathrm{p}<0.001$

LM negative rate Peason $\chi^{2}$ test $\mathrm{p}=0.574$

VM negative rate Peason $\chi^{2}$ test $\mathrm{p}=0.726$

Prognosis Peason $\chi^{2}$ test $\mathrm{p}<0.001$

Local recurrence rate Peason $\chi^{2}$ test $\mathrm{p}=0.42$

Table 2. Results

\section{Discussion}

In the present study, we have shown that the tumor size and negative horizontal margin rate are superior in ESD than EMRC. ESD is same complication risk as EMRC, however, did not suggest to be able to resect deeper lesions. Our results suggest that ESD is reliable technique for early superficial esophageal tumors.

In the previous study, Ishihara reported ESD using Hook knife has higher curative rate than EMRC or 2-channel EMR2. They had carried out ESD later than EMR or c-channel EMR, and they also suggested that continuous improvement of instruments and techniques as our study, however, regarding the limited size of the specimen of EMRC, more reliable resection is possible by ESD than EMRC. In addition, other studies suggests that piecemeal resection with EMR would be risk of local recurrence ${ }^{3}, 4$. Therefore, ESD is considered to be high curative rate for such lesions.

In spite of higher rate of en-bloc, curative resection, low risk of local recurrence and better histopathological evaluation of resected specimen, ESD is time-consuming and technically challenging. In this study, we did not evaluate procedure time. Oka also reported that average operation time was significantly longer in the ESD group than conventional EMR (84.4 minutes versus 12.6 minutes in total average $)^{5}$. Operation time is disadvantage of ESD, 
therefore, a various technique are improving to overcome this disadvantage. Neuhas indicated that procedure time could be shorten based on the learning curve, especially in ESD rather than EMR6, and this could be also affect endoscopist's experience, which related to early gastric lesions before esophageal lesions, since esophagus is more limited space and high risk for life-threating complications.

Several different technique using different knives has been reported to overcome the known difficulty of ESD ${ }^{7-10}$. And recently, some comparison study has also reported with various methods ${ }^{10-12}$. Takahashi compared ESD and EMR for early squamous cell carcinoma of the esophagus (SCCE) and reported higher cure rate and safer than conventional EMR, based on the hook-knife ESD method ${ }^{13}$. Oyama also emphasized the advantage of hook-knife ESD for esophageal lesions ${ }^{9}$, however, this device is still available only in the limited countries and also require special training because of the uniqueness of its shapes as well as insulated-tip diathermic knife (IT-knife) ${ }^{14}$. On the other hand, needle knife is available all over the world because it is approved as papillotome knife for ERCP already, and has been used without specialized training. Some authors had reported the feasibility and advantage of needleknife ESD15, 16, however, many endoscopist still consider that needle knife has higher complication risk for esophageal ESD. Therefore, we conducted the control study using needle-knife, and this is the first large scale, long-term study comparing ESD with conventional EMR of early esophageal neoplasm using needle knife. However, still there is no prospective randomized comparison study between these knives for esophageal ESD, therefore further multicenter study are needed.

The other concern is the risk of complications. Oka also reported that for bleeding and perforation, ESD was higher than conventional EMR (22.6\% versus 7.6\%, and $6.2 \%$ versus $3.9 \%$, respectively $)^{5}$. Our data also suggests that ESD has high complication risk of perforation; however, all these complications could be managed conservatively in most of the cases because of smaller size of perforation than conventional EMR. More than two of third of the circumferential resection in esophageal ESD is well known to develop delayed stenosis, which could be also safely managed using the balloon type dilator ${ }^{17}$.

\section{Conclusion}

In summery ESD was able to accomplish en-bloc resection and achieved larger resection than conventional EMR for early superficial tumors in the esophagus as well as other GI tract. There are some residual problems of operation time and complication, however, ESD has large advantage to cure the esophageal lesions and indispensable for superficial esophageal neoplasms. Further experiences and multi-center study are needed for compare the various devises.

\section{References}

[1] Inoue H, Takeshita K, Hori H, Muraoka Y, Yoneshima H, Endo M. Endoscopic mucosal resection with a cap-fitted panendoscope for esophagus, stomach, and colon mucosal lesions. Gastrointest Endosc 1993;39:58-62.

[2] Ishihara R, Iishi H, Uedo N, Takeuchi Y, Yamamoto S, Yamada T, Masuda E, Higashino K, Kato M, Narahara H, Tatsuta M. Comparison of EMR and endoscopic submucosal dissection for en bloc resection of early esophageal cancers in Japan. Gastrointest Endosc 2008;68:1066-72. 
[3] Katada C, Muto M, Manabe T, Ohtsu A, Yoshida S. Local recurrence of squamous-cell carcinoma of the esophagus after EMR. Gastrointest Endosc 2005;61:219-25.

[4] Tanabe S, Koizumi W, Mitomi H, Kitamura T, Tahara K, Ichikawa J, Higuchi K, Sasaki T, Nakayama N, Kida M, Saigenji K. Usefulness of EMR with an oblique aspiration mucosectomy device compared with strip biopsy in patients with superficial esophageal cancer. Gastrointest Endosc 2004;59:558-63.

[5] Oka S, Tanaka S, Kaneko I, Mouri R, Hirata M, Kawamura T, Yoshihara M, Chayama K. Advantage of endoscopic submucosal dissection compared with EMR for early gastric cancer. Gastrointest Endosc 2006;64:877-83.

[6] Neuhaus H, Wirths K, Schenk M, Enderle MD, Schumacher B. Randomized controlled study of EMR versus endoscopic submucosal dissection with a water-jet hybridknife of esophageal lesions in a porcine model. Gastrointest Endosc 2009;70:112-20.

[7] Ono H, Kondo H, Gotoda T, Shirao K, Yamaguchi H, Saito D, Hosokawa K, Shimoda T, Yoshida S. Endoscopic mucosal resection for treatment of early gastric cancer. Gut 2001;48:225-9.

[8] Yamamoto H, Kawata H, Sunada K, Satoh K, Kaneko Y, Ido K, Sugano K. Success rate of curative endoscopic mucosal resection with circumferential mucosal incision assisted by submucosal injection of sodium hyaluronate. Gastrointest Endosc 2002;56:507-12.

[9] Oyama T, Tomori A, Hotta K, Morita S, Kominato K, Tanaka M, Miyata Y. Endoscopic submucosal dissection of early esophageal cancer. Clin Gastroenterol Hepatol 2005;3:S67-70.

[10] Yahagi N, Neuhaus H, Schumacher B, Neugebauer A, Kaehler GF, Schenk M, Fischer K, Fujishiro M, Enderle MD. Comparison of standard endoscopic submucosal dissection (ESD) versus an optimized ESD technique for the colon: an animal study. Endoscopy 2009;41:340-5.

[11] Nonaka K, Arai S, Ishikawa K, Nakao M, Nakai Y, Togawa O, Nagata K, Shimizu M, Sasaki Y, Kita H. Short term results of endoscopic submucosal dissection in superficial esophageal squamous cell neoplasms. World J Gastrointest Endosc 2010;2:69-74.

[12] Teoh AY, Chiu PW, Yu Ngo DK, Wong SK, Lau JY, Ng EK. Outcomes of endoscopic submucosal dissection versus endoscopic mucosal resection in management of superficial squamous esophageal neoplasms outside Japan. J Clin Gastroenterol 2010;44:e190-4.

[13] Takahashi H, Arimura Y, Masao H, Okahara S, Tanuma T, Kodaira J, Kagaya H, Shimizu Y, Hokari K, Tsukagoshi H, Shinomura Y, Fujita M. Endoscopic submucosal dissection is superior to conventional endoscopic resection as a curative treatment for early squamous cell carcinoma of the esophagus (with video). Gastrointest Endosc 2010;72:255-64, 264 e1-2.

[14] Gotoda T. A large endoscopic resection by endoscopic submucosal dissection procedure for early gastric cancer. Clin Gastroenterol Hepatol 2005;3:S71-3.

[15] Yamamoto H. Endoscopic submucosal dissection of early cancers and large flat adenomas. Clin Gastroenterol Hepatol 2005;3:S74-6.

[16] Kita H, Yamamoto H, Miyata T, Sunada K, Iwamoto M, Yano T, Yoshizawa M, Hanatsuka K, Arashiro M, Omata T, Sugano K. Endoscopic submucosal dissection 
using sodium hyaluronate, a new technique for en bloc resection of a large superficial tumor in the colon. Inflammopharmacology 2007;15:129-31.

[17] Mizuta H, Nishimori I, Kuratani Y, Higashidani Y, Kohsaki T, Onishi S. Predictive factors for esophageal stenosis after endoscopic submucosal dissection for superficial esophageal cancer. Dis Esophagus 2009;22:626-31. 


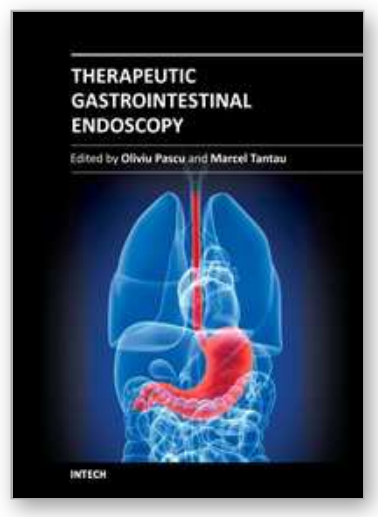

\author{
Therapeutic Gastrointestinal Endoscopy \\ Edited by Prof. Oliviu Pascu
}

ISBN 978-953-307-743-7

Hard cover, 216 pages

Publisher InTech

Published online 22, September, 2011

Published in print edition September, 2011

Endoscopy has had a big role in the development of modern gastroenterology. Modern endoscopy will certainly be more therapeutic. It started with endoscopic hemostasis and polipectomy, than beginning of the 1970 's with the advent of endoscopic sphincterotomy extended to biliopancreatic pathology and has a huge impact in this difficult pathology. Plastic stents made the first steps in endoscopic palliation of neoplastic jaundice, metallic stents, covered or uncovered are better for biliary palliation and can be used also for palliation neoplastic obstruction at different levels of the digestive tube. Resection of digestive tumors has evolved now to sub-mucosal resection, looking to have one-piece complete resection. Interventional endoscopy is now very complex and takes a lot of time for endoscopists to learn properly these techniques. This book is a very good up-to-date overview of new techniques of interventional endoscopy for those who want to learn or develop their knowledges in this field.

\title{
How to reference
}

In order to correctly reference this scholarly work, feel free to copy and paste the following:

Makoto Nishimura, Masafumi Sakaguchi, Hideki Kitada, Michio Hifumi and Hiroto Kita (2011). Endoscopic Submucosal Dissection, a New Technique for en Bloc Resection of Large Superficial Tumor in the Esophagus, Therapeutic Gastrointestinal Endoscopy, Prof. Oliviu Pascu (Ed.), ISBN: 978-953-307-743-7, InTech, Available from: http://www.intechopen.com/books/therapeutic-gastrointestinal-endoscopy/endoscopic-submucosaldissection-a-new-technique-for-en-bloc-resection-of-large-superficial-tumor-in

\section{INTECH}

open science | open minds

\section{InTech Europe}

University Campus STeP Ri

Slavka Krautzeka 83/A

51000 Rijeka, Croatia

Phone: +385 (51) 770447

Fax: +385 (51) 686166

www.intechopen.com

\section{InTech China}

Unit 405, Office Block, Hotel Equatorial Shanghai

No.65, Yan An Road (West), Shanghai, 200040, China

中国上海市延安西路65号上海国际贵都大饭店办公楼 405 单元

Phone: +86-21-62489820

Fax: $+86-21-62489821$ 
(C) 2011 The Author(s). Licensee IntechOpen. This chapter is distributed under the terms of the Creative Commons Attribution-NonCommercialShareAlike-3.0 License, which permits use, distribution and reproduction for non-commercial purposes, provided the original is properly cited and derivative works building on this content are distributed under the same license. 